\title{
THE INFLUENCE OF DESTINATION IMAGES ON REVISIT INTENTION IN MOUNT BATUR
}

\author{
Ni Ketut Wiwiek Agustina. \\ Sekolah Tinggi Pariwisata Nusa Dua Bali
}

\begin{abstract}
Tourism has become one of idol business in Indonesia, which can be seen by the graph of performance continues to rise up compared to oil, gas, coal, and palm oil which continue to decline. Each destination tries to serve tourists better using many kinds of strategies, one of them is the destination image. This research aims to analyze the influence of destination image on the revisit intention in Mount Batur, Bali. The study is explanatory and done using quantitative and descriptive approaches. The number of samples to be used is 100 samples. The method of data collection is done by questionnaire collection method to analyze the influence of the destination image variable on the variable of revisit intention obtained by descriptive explanation. Based on the results of the research conducted, it shows that the image of the destination has a significant effect on the interest in returning to tourists in Mount Batur, which means that the hypothesis proposed in the study was accepted. This can be seen in the results of the hypothesis test the value of $t$ arithmetic obtained is equal to 7.242 with a significance value of 0.000 smaller than 0.05 . Based on the correlation test, the relationship between the two variables is at a moderate level with a percentage of influence of $34.9 \%$. So that from this it is expected that tourists area managers of Mount Batur must try to maintain security, comfort and the environment .
\end{abstract}

Keywords: Destination Image, Revisit Intention, Mount Batur

\section{INTRODUCTION}

The tourism industry is becoming an idol in Indonesia. This can be seen from the increased performance every year. The graph is very contrast compared to other commodities, such as oil, gas, coal, and palm oil which continue to decline. In addition, tourism is also considered to have advantages because the majority of its activities are in the service sector. Tourism is also the most sustainable commodity and reaches the lowest level of society (https://www.liputan6.com accessed 8/12/2018)

Therefore the government put a lot of attention to the development of tourism in Indonesia. Tourism destinations are part of Indonesia's tourism development. The scope of the components of a tourism destination includes tourist objects and attractions, accessibility, amenities (tourist support facilities), supporting facilities, and institutions (sunaryo, 2013). The purpose of the tourist 
destination manager is to determine the right way for tourists to return to their destination. As a manager, the strategy must be planned in an effort to create a sense of wanting to revisit. In general, destination image is when the process of management of a tourist destination goes well so that it can provide long-term effects on consumers, which can be interpreted as the possibility of domestic and foreign tourists having the desire to revisit or repeat activities at a destination (Lin, 2012 )

Bali is one of the most famous international tourist destinations in the world. The tourism sector has been a driving force for the economy and development in Bali since the 1970s. Therefore tourism is a very close and inseparable part of people's lives and development in Bali. The unique and diverse beauty of Bali's nature and culture which is guided or guided by Hindu philosophy and natural beauty is the main attraction for tourists, both domestic and foreign tourists. One of the tourism sectors is the beauty of Batur volcano, located in Kintamani District, Bangli district.

The Kintamani tourism area is in the northeastern part of Bali and is below the caldera of Mount Batur, one of the active volcanoes in Bali. Besides there is a volcano, in the tourist area of Kintamani tourists can also see a natural lake named Lake Batur. In the Kintamani tourism area there are several villages. Such as Penelokan village, Abung village, Songan village, ToyaBungkah village, Batur village, Kedisan village, and Kintamani village which are included in the Bangli district government. Mount Batur as a tourism destination, in its development certainly requires several benchmarks, one of which is from the tourists. Tourists are considered important to assess a destination because tourists are buyers or connoisseurs of services offered by tourism destinations. Travelers value a destination through their beliefs and perceptions, which can then be referred to as destination images. So that by knowing the opinions of tourists regarding the image of the Mount Batur destination, it is expected that tourism development in the Mount Batur region can be in harmony with what tourists need and want. So that tourists can get satisfaction and plan to repeat their visit in the future or at least recommend Mount Batur as one of the tourism destinations that deserve to be visited by others. In addition, it can be seen what factors need to be maintained and improved from the attributes of tourism in Mount Batur and analyze whether there is a negative rating of tourists from the image of Gunung Batur so that improvements are needed to support the quality of a better tourism destination.

\section{LITERATURE REVIEW}

\section{Image}

Image is the perspective of the community in assessing a product from the company. But people are often confused about image and identity, identity is a way of positioning products that are owned by the company to create a corporate identity. The company designs an identity or positioning to shape the image of society, but other factors may influence the image that is accepted by each person. There are three effective ways to develop images in the eyes of consumers. First, determining the value or character of the product owned. Second, giving the impression that the difference in the image of a product has its own uniqueness compared to other 
companies. Third, sending emotional strength so as to arouse the heart and mind of the buyer. Generating a strong image requires creativity and hard work. It takes a long time to make people believe in the image of the product that the company has.

\section{Destination}

Destinations are a unity of tourist destination products which in which consist of several types of organizations and tourism operations in their geographic areas, including accommodation, transportation, attractions, etc. Tourism destinations include everything in the region, its people, landscapes, other industries and other things that can be part of the destination experience, local specialties that can be enjoyed by tourists even though they are not part of the tourism economy specifically. Destinations within the framework of development include several main components. The main component according to Sunaryo (2013) is divided into five, including objects and tourist attractions, accessibility, amenities, ancillary services, and institutions.

\section{Destination Image}

According to (Echtner, 1991) the destination image is a number of beliefs and judgments of an attraction or activity in a destination that shapes the overall picture of the destination. Whereas the perceived image after the occurrence of a tourist visit will also affect consumer satisfaction and intensity to conduct a return visit in the future, depending on the ability of the tourist destination in providing an experience that is in accordance with the image needs that tourists have about tourist areas. A good destination is a destination that must be able to provide tourist facilities that are appropriate to the needs of visitors to provide convenience and meet their needs during the visit. The ability to provide tourist facilities, make visitors comfortable when visiting (Kotler, 2009) states that facilities are all things that are intentionally provided by service providers to be used and enjoyed by consumers aimed at providing maximum levels of satisfaction. Facilities tend to support rather than push and tend to develop at the same time or after the attraction developed (Loebbecke, 1997). The instruments used to measure destination image variables are nine indicators, namely environment, nature tourism, events and entertainment, historical/cultural attractions, infrastructure, accessibility, relaxation, outdoor activities, as well as price and value.

1. Environment, namely the state of the environment in and around tourist attractions. This includes the security of tourist sites, cleanliness, residents' hospitality, and tranquility of the atmosphere.

2. Nature tourism, is a state of nature tourism or the beauty of the scenery in a tourist attraction

3. Events and entertainment, namely a variety of events and entertainment that are presented at tourist sites

4. Historical/cultural attractions, the state of local culture that is a characteristic of tourist attractions

5. Infrastructure, supporting facilities that are in and around tourist attractions

6. Accessibility, fluency or ease of access to reach tourist sites

7. Relaxation, that is a condition or condition where a tourist object can help visitors to calm their mind and refresh their body. 
8. Outdoor activities, namely activities that can be carried out by visitors in the open in and around tourist attractions

9. Prices and values, all costs incurred by visitors/tourists while they are in tourist attractions.

\section{Revisit Intention}

Revisit intention is a feeling of wanting to revisit a tourist destination in the future. Travelers who have an interest in revisiting can be marked by a willingness to review the same destination in the future and recommend destinations to others. Repeated holidays in the same place and expressing the intention to make a repeat visit are two signs of loyalty to destinations that are often taken into account in the tourism literature (Alegre, 2009). The feeling of wanting to revisit a similar tourist destination can appear for several reasons. According to (Alegre, 2009), the reason or main factor that determines the interest to return to a destination is satisfaction during the visit, certain motivation in choosing a tourist destination, and the tourist's love of the destination. Tourists' love of destinations can be measured by the number of repeat visits made by these tourists.

The four factors that influence the interest of returning customers to a tourist attraction are expressed by (Hsu, 2009) in their journal "Effects of Travel Motivation, Past Experience, Perceived Constraints, and Attitude on Revisit Intention", those are:

1. Travel Motivation

Many factors motivate tourists to visit again, so a company must see what motivates tourists to return.

2. Past Experience

Reflect on the good experiences of other previous travelers so that they can give other travelers the desire to visit a destination.

3. Perceived Constraint

In order to see what are the obstacles that will be faced by tourists in making a visit.

4. Attitude

Seeing from the attitude of tourists who come happy or not with the existing conditions.

The dimensions used in this study are the dimensions put forward by (Lin, 2012) there are also two dimensions, namely:

1. Intention to Recommend (desire to recommend to others)

2. Intention to Revisit (Desire to return to visit)

\section{Hypothesis}

In accordance with the formulation of the problem and the literature review, the hypothesis proposed in the research is: the destination image has significant influence on the revisit intention.

\section{RESEARCH METHODS}

The research site was conducted at Mount Batur tourist attraction, the precise locus at Bromo Bungkah, Batur village, Kintamani district, Bangli regency, Bali province. The object of research used regarding the image of the destination and 
interest in revisiting tourists. The population chosen in this study were tourists visiting the Mount Batur tourist attraction with the method of determining the sample used accidental sampling, namely the technique of determining samples based on chance, that is, anyone who accidentally met with a researcher could be used as a sample, if the person who happened to be met considered suitable as a data source (Sugiyono, 2017) so that a sample of 100 (one hundred) tourists was taken.

Furthermore, the data collection method used is a questionnaire. The scale of data collection used in this study is the Likert scale. According to (Sugiyono, 2017) the Likert scale can be used to measure attitudes, opinions, and perceptions of a person or group about social phenomena. In this study the respondent's answers were assessed with 5 rating points, 1 if strongly disagreed, 5 strongly agreed.

\section{Data analysis technique}

1. Test Instrument

a. Validity test

Validity test is used to measure the validity or validity of a questionnaire, a questionnaire is declared valid if the question in the questionnaire is able to express something that will be measured by the questionnaire (Ghozali, 2016). Testing is done by correlating the scores of items for each item with a total score. Furthermore, the interpretation of correlations produced is compared with label. If the correlation is less than 0.30 then the item question in the instrument is declared invalid. Instrument item is declared valid if the Pearson correlation value is more than 0.30 .

b. Reliability Test

Reliability test is a tool to measure a questionnaire which is an indicator of a variable. A questionnaire is said to be reliable or reliable if someone's answer to the statement is consistent over time. To find out whether a variable is reliable or not, a statistical test is performed by looking at the value of Cronbach Alpha (Ghozali, 2016). If the value of Cronbach Alpha is above 0.70 , the questions used to measure these variables are "reliable". And vice versa, if the value of Cronbach Alpha is below 0.70, the questions used to measure the variable are "unreliable". Measurement of validity and reliability is absolutely necessary, because if the instrument used is invalid and reliable, then the research is invalid and reliable, (Sugiyono, 2017).

\section{Simple Linear Regression Test}

Regression analysis is the coefficient for each independent coefficient. This coefficient is obtained by predicting the value of the independent variable with an equation. Regression coefficients with two objectives at once, first minimize deviations between the value of actuation with the estimated value of independent variables based on existing data (Ghozali, 2016) With the equation as follows:

$$
\mathrm{Y}=\beta \mathrm{o}+\beta 1 \mathrm{X} 1
$$

\footnotetext{
Remarks;

$\mathrm{Y}=$ Interest in returning

$\beta 0=$ Constants
} 
$\beta 1-\beta 2=$ Regression Coefficient

$\mathrm{X}=$ Destination Image

$\mathrm{e}=$ Disturbing component

a. Multiple Correlation Analysis

This analysis is used to determine the degree of influence simultaneously between independent variables and dependent variables. Interpretation criteria for correlation coefficient (Sugiyono, 2009)

Table 1

Interpretation of interpretations of the correlation coefficient Relationship Level Coefficient Interval

\begin{tabular}{|c|c|}
\hline Interval Koefisien & Tingkat Hubungan \\
\hline $0,000-0,199$ & Very low \\
$0,200-0,399$ & Low \\
$0,400-0,599$ & Average \\
$0,600-0,799$ & Strong \\
$0,800-1,000$ & Very Strong \\
& \\
\hline
\end{tabular}

b. The coefficient of Determination $\left(\mathrm{R}^{2}\right)$

The coefficient of determination is between zero and one. A small $\mathrm{R}^{2}$ value means the ability of independent variables to provide almost all the information needed to predict variations in the dependent variable. The weakness of the coefficient of determination $\left(\mathrm{R}^{2}\right)$ is a bias towards the number of independent variables entered into the model. Each additional an independent variable then $\left(\mathrm{R}^{2}\right)$ must increase no matter whether the variable has a significant effect on the dependent variable. Therefore, in this study used the value of Adjusted $\mathrm{R}^{2}$. Adjusted $\mathrm{R}^{2}$ values can go up or down if an independent variable is added to the model.

\section{c. Statistical test $\mathrm{t}$}

The $t$ statistical test basically shows how far the influence of an explanatory variable / independent individually in explaining the variable variation of the ministry (Ghozali, 2016). The t-test can be done by looking at the significance values of each variable. The criteria for decision making are:

1) If the significant value of the independent variable is less than 0.05 , the independent variable has an effect on the dependent variable.

2) If the significant value of the independent variable is more than 0.05 , it means that the independent variable has no effect on the dependent variable. 


\section{RESULTS AND DISCUSSION Descriptive Analysis Results}

The results of tourist perceptions of the three indicators used to measure the image of the Mount Batur and interest in returning are presented in table 2 below:

Table 2

Tourists' Perception

\begin{tabular}{|c|c|c|}
\hline Num. & Indicator & Average \\
\hline \multicolumn{3}{|c|}{ Destination Image $\left(\mathrm{X}_{1}\right)$} \\
\hline 1 & $\begin{array}{l}\text { Many Travel Agencies help to get tourist } \\
\text { information and facilities }\end{array}$ & $\begin{array}{l}4.48 \\
\text { (Strongly } \\
\text { agree) }\end{array}$ \\
\hline 2 & $\begin{array}{l}\text { Tourism Information Center provides } \\
\text { convenience in obtaining information }\end{array}$ & $\begin{array}{c}4.27 \\
\text { (Agree) }\end{array}$ \\
\hline 3 & Easy to find transportation to/from attraction & $\begin{array}{c}4.21 \\
\text { (Agree) }\end{array}$ \\
\hline 4 & Good road access in Mount Batur & $\begin{array}{c}4.34 \\
\text { (Agree) }\end{array}$ \\
\hline 5 & Ease of access to health services & $\begin{array}{c}4.25 \\
\text { (Agree) }\end{array}$ \\
\hline 6 & $\begin{array}{l}\text { Strong and good telecommunications signals } \\
\text { and networks }\end{array}$ & $\begin{array}{c}4.17 \\
\text { (Agree) }\end{array}$ \\
\hline 7 & $\begin{array}{l}\text { Many special interests attractions e.g hot } \\
\text { springs }\end{array}$ & $\begin{array}{c}4.26 \\
\text { (Agree) }\end{array}$ \\
\hline 8 & Many culinary attractions & $\begin{array}{c}4.17 \\
\text { (Agree) }\end{array}$ \\
\hline 9 & Interesting nature scenery & $\begin{array}{c}4.08 \\
\text { (Agree) }\end{array}$ \\
\hline \multicolumn{3}{|c|}{ Revisit Intention (Y) } \\
\hline 10 & I really like the tourist attraction in Mount Batur & $\begin{array}{c}4.46 \\
\text { (Agree) }\end{array}$ \\
\hline 11 & I will visit again & $\begin{array}{c}4.24 \\
\text { (Agree) }\end{array}$ \\
\hline 12 & I will recommend to friends and family & $\begin{array}{c}4.34 \\
\text { (Agree) }\end{array}$ \\
\hline
\end{tabular}




\begin{tabular}{|l|l|c|}
\hline 13 & $\begin{array}{l}\text { I will visit other attractions for longer periods of } \\
\text { time }\end{array}$ & $\begin{array}{c}4.23 \\
\text { (Agree) }\end{array}$ \\
\hline
\end{tabular}

Source: processed data

Based on Table 2, it can be seen that the highest rating related to destination image is the first question, "Many Travel Agencies help to get tourist information and facilities" with an average value of 4.48 which means that tourists have a lot of information about Mount Batur attractions. The highest rating related to interest in returning is in the statement "I will recommend to friends and family" with an average of 4.34, which means tourists who have visited are happy to recommend Mount Batur as one of the best tourist attractions in Bali.

Instrument Test Results

\section{1) Test Validity}

Validity test is used to measure the validity or validity of a questionnaire, a questionnaire is declared valid if the question in the questionnaire is able to express something that will be measured by the questionnaire (Ghozali, 2016). The results of the validity test can be seen in Table 3 , as follows.

Table 3

Validity Test Result

\begin{tabular}{|c|c|c|c|}
\hline Question item & $\begin{array}{c}\text { Pearson } \\
\text { Correlation }\end{array}$ & Sig & Remarks \\
\hline \multicolumn{4}{|c|}{ Destination Image (X) } \\
\hline $\mathrm{X}_{1.1}$ & 0,362 & 0,000 & Valid \\
\hline $\mathrm{X}_{1.2}$ & 0,562 & 0,000 & Valid \\
\hline $\mathrm{X}_{1.3}$ & 0,523 & 0,000 & Valid \\
\hline $\mathrm{X}_{1.4}$ & 0,371 & 0,000 & Valid \\
\hline $\mathrm{X}_{1.5}$ & 0,595 & 0,000 & Valid \\
\hline $\mathrm{X}_{1.6}$ & 0,579 & 0,000 & Valid \\
\hline $\mathrm{X}_{1.7}$ & 0,381 & 0,000 & Valid \\
\hline $\mathrm{X}_{1.8}$ & 0,532 & 0,000 & Valid \\
\hline $\mathrm{X}_{1.9}$ & 0,576 & 0,000 & Valid \\
\hline $\mathrm{Y}_{1.1}$ & Revisit Intention $(\mathbf{Y})$ & Valid \\
\hline $\mathrm{Y}_{1.2}$ & 0,667 & 0,000 & Valid \\
\hline $\mathrm{Y}_{1.3}$ & 0,895 & 0,000 & Valid \\
\hline $\mathrm{Y}_{1.4}$ & 0,654 & 0,000 & Valid \\
\hline
\end{tabular}

Source: processed data

Instrument item is declared valid if the Pearson correlation value is more than 0.30. In Table 3 it can be seen that all indicators used to measure the variables in this study have a person correlation value greater than 0.30 and significance is smaller than 0.05 so it can be concluded that all indicators used are declared valid. 
2) Reliability Test

Reliability test is a tool to measure a questionnaire which is an indicator of a variable. A questionnaire is said to be reliable or reliable if someone's answer to the statement is consistent over time. The reliability test results can be seen in Table 4 as follows:

Table 4.

Reliability Test Result

\begin{tabular}{|l|c|c|}
\hline \multicolumn{1}{|c|}{ Variable } & Cronbach's Alpha & Remarks \\
\hline Destination Image (X) & 0,710 & Reliabel \\
\hline Revisit Intention (Y) & 0,811 & Reliabel \\
\hline
\end{tabular}

Source: processed data

The questions used to measure variables are declared reliable if the Cronbach Alpha value is above 0.70. Based on Table 4 above, it can be seen that all statements relating to the independent variable have a Cronbach's alpha value bigger than 0.70 so that it can be concluded that all data used in the questionnaire are said to be reliable.

Classic assumption test

1. Heteroscedasticity test

This test is carried out by the Glejser test, namely by regression of the absolute residual value of the model estimated on the independent variable. The heteroscedasticity test results can be seen in Table 5 below:

Table 5

Heteroscedasticity Test Result

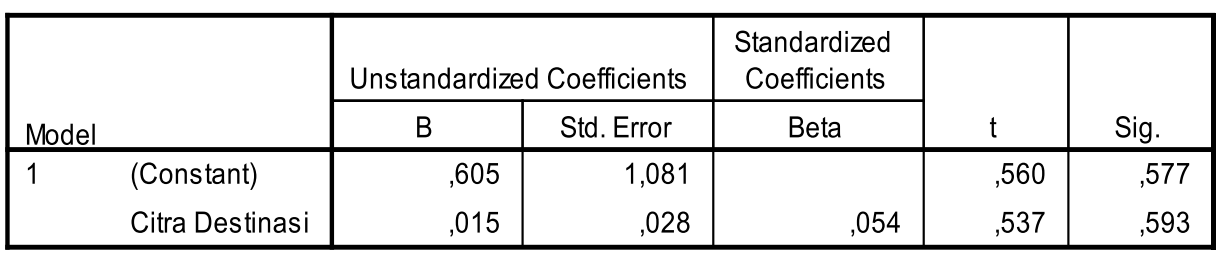

Dependent Variable: ABRES

source: processed data

Based on Table 5, by regression, the residual absolute value (abres) can be seen in the sig column. that the significant value of the independent variables used in the study has a significance value of 0.593 greater than 0.05 so it can be concluded that the variables used in the study have no symptoms of heteroscedasticity.

\section{Simple Linear Regression Analysis}

Simple linear regression analysis is used to find out or obtain an overview of the effect of independent variables on the dependent variable. The influence of 
destination image independent variables on the dependent variable of visiting interest is presented in Table 6 below:

Table 6

Simple Linear Regression Analysis Result

\begin{tabular}{|c|c|c|c|c|c|c|}
\hline \multirow{2}{*}{\multicolumn{2}{|c|}{ Model }} & \multicolumn{2}{|c|}{ Unstandardized Coefficients } & \multirow{2}{*}{$\begin{array}{c}\text { Standardized } \\
\text { Coefficients } \\
\text { Beta } \\
\end{array}$} & \multirow[b]{2}{*}{$\mathrm{t}$} & \multirow[b]{2}{*}{ Sig. } \\
\hline & & B & Std. Error & & & \\
\hline \multirow[t]{2}{*}{1} & (Constant) & 4,700 & 1,742 & & 2,698 &, 008 \\
\hline & Citra Destinasi & ,329 & ,045 &, 590 & 7,242 &, 000 \\
\hline
\end{tabular}

Dependent Variable: Minat Berkunjung Kembali

source: processed data

From the results of the regression analysis in Table 6, it can be seen in the Unstandardized Coefficients column in the value B so that the regression equation is arranged as follows:

\section{$\mathrm{Y}=4,700+0,329$}

Based on the results of the equation, it can be explained the pattern of the influence of the Destination Image (X) on the Revisit Intention (Y), as follows:

- $\mathrm{a}=4,700$ means that if the image of the destination does not change or remains, then the amount of interest in returning to tourists is 4,700 .

- $b 1=0.329$ means that if the destination image increases by one unit then the level of interest in returning tourists will increase by 0.329 . This means that every increase in destination image also increases interest in returning a) Correlation Test Results

Correlation is a statistical test to determine the strength or weakness of the relationship between independent variables and the dependent variable whose results can be seen in Table 7 below.

Table 7

Simple Correlation Test Result

\begin{tabular}{|l|r|r|r|c|}
\hline $\begin{array}{l}\text { Mode } \\
1\end{array}$ & R & R Square & $\begin{array}{c}\text { Adjusted R } \\
\text { Square }\end{array}$ & $\begin{array}{c}\text { Std. The } \\
\text { error of the } \\
\text { Estimate }\end{array}$ \\
\hline 1 &, $590^{\mathrm{a}}$ &, 349 &, 342 & 1,52461 \\
\hline
\end{tabular}

a. Predictors: (Constant), Destination Image

b.

Dependent Variable: Revisit Intention

Based on Table 7 can be seen in column R, which is a correlation value of 0.590 . Based on criteria, the value is between $0.400-0.599$, which means there is a relationship with the moderate level between Destination Image and Revisit Intention to Mount Batur. 
b) Determination Test Results

A determination is a statistical test to determine the percentage of influence between independent variables on the dependent variable. Based on Table 8 in the R Square column, it can be seen that the determination value is 0.349 or $34.9 \%$. This means that 34.9 percent of visiting interest is again influenced by the image of the destination. The remaining $65.1 \%$ is influenced by variables outside the study.

c) Hypothesis Testing (t-test)

Hypothesis testing is done by using a significance level of $0.05(\alpha=5 \%)$.

The results of t-test can be seen in Table 8 as follows:

Table 8

T-Test Result

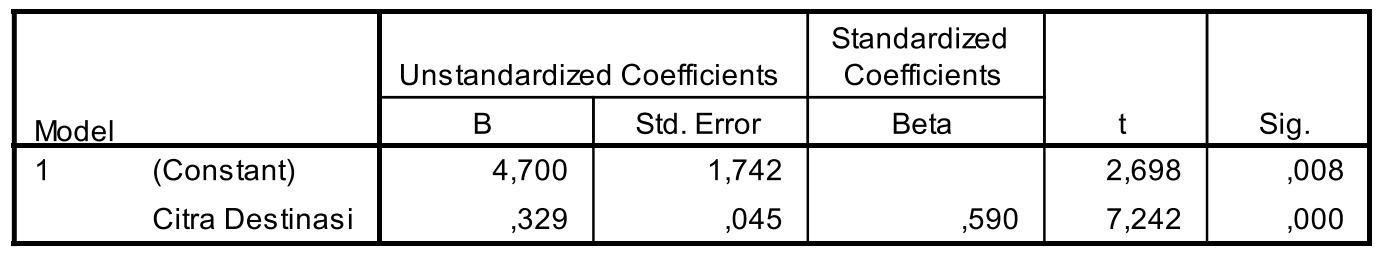

Dependent Variable: Minat Berkunjung Kembali

Based on the test results in Table 8 can be seen in columns $t$ and Sig which can be explained that the value of destination image $t$ count $(\mathrm{X})$ is 7,242 with a significant value of 0,000 smaller than 0.05 this means that the destination image $(\mathrm{X})$ has a significant effect on revisit intention $(\mathrm{Y})$.

\section{DISCUSSION}

The results of the study show that the image of the destination has a significant effect on the revisit intention to Mount Batur, which means that the hypothesis proposed in the study is accepted. This can be seen in the results of the hypothesis test the value of $t$ arithmetic obtained is equal to 7.242 with a significance value of 0.000 smaller than 0.05 . Based on the correlation test, the relationship between the two variables is at a moderate level with a percentage of influence of $34.9 \%$.

According to visitors who have visited, Mount Batur is one of the best tourist attractions in Bali that is a must-visit attraction.

The results of this study are in line with the results of research obtained by Aviolitasoa (2017), FitriHayati (2016) and Handawan (2015) who obtained a destination image results significantly positive effect on the interest of tourists to visit again.

\section{CONCLUSIONS}

Based on the discussion described previously, it can be concluded that the image of the destination has a significant effect on the interest in visiting tourists to 
Mount Batur. This means that the better the destination image of Mount Batur, the more tourists who will visit will return to the Mount Batur. Vice versa, if the destination image is built to deteriorate.

Based on the conclusions taken in this study is the significance of the influence of the destination image on the interest in visiting again, it is expected that the managers of the tourist area in Mount Batur can build a positive image.

\section{REFERENCES}

Alegre, J. a. M. C. (2009). Analysing the effect of satisfaction and previous visits on tourist intentions to return. European Journal of Marketing., 43 (5/6).

Echtner, C. M., Ritchie, J. R. B. (1991). The Meaning and Measurement of Destination Image. The Journal of Tourism Studies, 2 (2), pp. 2-12.

Ghozali. (2016). Multinomial Logistic Regression (Vol. jilid 1).

Hsu, S. S. H. d. C. H. C. (2009). Effects of Travel Motivation, Past Experience, Perceived Constraint, and Attitude on Revisit Intention.

kotler, p. (2009). manajemen keuangan. jakarta: erlangga.

Lin, C. H. (2012). Effects of Cuisine Experience, Psychological Well-Being, And SelfHealth Perception on the Revisit Intention of Hot Springs Tourist. Journal of Hospitality \& Tourism Research, p. 1-22

Loebbecke, J. K. (1997). Auditing an Integral Approach. Prentice Hall,: Inc.

Sugiyono. (2009). Metode Penelitian Kuantitatif. Bandung: Alfabeta.

Sugiyono. (2017). Metode Penelitian Pendidikan Pendekatan Kuantitatif, Kualitatif, dan $R \& D$. bandung.

sunaryo, b. (2013). Kebijakan pembangunan destinasi pariwisata konsep dan aplikasinya di Indonesia. yogyakarta: gava media.Internet

http://eprints.iain-surakarta.ac.id/1705/1/full\%20skripsi.pdf

https://media.neliti.com/media/publications/87276-ID-pengaruh-citra-destinasiterhadap-kepuas.pdf

http://administrasibisnis.studentjournal.ub.ac.id/index.php/jab/article/download/22 $\underline{79 / 2680}$

https://media.neliti.com/media/publications/87276-ID-pengaruh-citra-destinasiterhadap-kepuas.pdf

https://www.liputan6.com/lifestyle/read/3650849/industri-pariwisata-indonesiakian-meningkat-pesat 